\title{
Spring Device
}

National Cancer Institute

\section{Source}

National Cancer Institute. Spring Device. NCI Thesaurus. Code C50187.

An elastic device designed to bend under a load and then return to its shape when unloaded. 